\title{
Rekayasa Penghancur Limbah Jarum Suntik Menggunakan Metode Melting
}

\author{
Sigit Widadi*1 ${ }^{1}$, Muhammad Nashirudin ${ }^{2}$ \\ Universitas Muhammadiyah Yogyakarta, Indonesia
}

INFO ARTIKEL

Alamat Web Artikel:

https://journal.umy.ac.id/index.php/

$\mathrm{mt} /$ article/view/11461

DOI:

https://doi.org/10.18196/mt.v2i2.11461

Data Artikel:

Diterima:

09 Februari 2021

Direview:

16 Februari 2021

Direvisi :

29 Maret 2021

Disetujui :

31 Maret 2021

Korespondensi:

swdskom@umy.ac.id

\begin{abstract}
ABSTRAK
Penanganan limbah medis membutuhkan cara yang tepat agar tidak menimbulkan dampak kesehatan. Penelitian ini menyajikan rekayasa mesin penanganan limbah jarum suntik agar proses dan hasil olahan limbah aman bagi manusia dan lingkungan. Metode Yang digunakan yaitu melting. Rancangan mesin menggunakan sensor infrared dan optocoupler sebagai detektor objek untuk motor feeder dan tansformator. Hasil pengujian menunjukkan bahwa metode ini tidak menimbulkan polusi suara dan debu logam.
\end{abstract}

Kata Kunci: Limbah Medis, Jarum Suntik, Melting

\begin{abstract}
Handling medical waste requires proper treatment to avoid health impacts. This research presents the engineering of syringe waste handling machines so that the processed waste products are safe for both humans and the environment through the melting method. The device's design uses an infrared sensor and an optocoupler as an object detector for the motor feeder and transformer. The test showed that the method did not cause noise pollution nor metal dust.
\end{abstract}

Keywords: Medical Waste, Syringes, Melting

\section{PENDAHULUAN}

Limbah medis merupakan limbah yang perlu pemrosesan khusus agar tidak menjadi media penyebaran penyakit atau menjadi penyebab terjadinya suatu insiden[1]. Salah satu limbah medis yang berbahaya adalah jarum suntik bekas pakai yang biasanya ditimbulkan dari suatu tindakan medis di rumah sakit. Benda tajam seperti ini dapat menjadi penyebab terjadinya luka pada kaki karena benda tersebut sering ditemukan di tempat pembuangan sampah.

Di Indonesia masih banyak unit layanan kesehatan yang belum memiliki alat penghancur limbah jarum suntik. Pada umumnya jarum suntik hanya disterilkan menggunakan zat klorin sebelum dibuang bersama dengan limbah lainnya[2]. Meskipun setiap kurun waktu tertentu sampah medis didaur ulang bersama dengan limbah lainnya namun tetap membahayakan bagi manusia pada saat melakukan proses daur ulang sampah tersebut. Pada sisi lainnya, limbah medis jarum suntik dapat digunakan kembali oleh orang yang tidak bertanggung jawab untuk keperluan diluar ketentuan [3].

Limbah jarum suntik yang digunakan kembali sangat membahayakan kesehatan manusia karena akan menyebabkan penularan penyakit seperti hepatitis dan HIV/AIDS, oleh karena itu limbah jarum suntik harus dihancurkan dengan benar[4]. Untuk mecegah pihak yang tidak bertanggung jawab dan menghindari risiko infeksi virus atau bakteri dari benda tersebut maka dibutuhkan mesin penghancur yang mampu mengubah wujud menjadi serbuk maupun lelehan.

Pada penelitian sebelumnya diperoleh hasil berupa mesin pengancur limbah jarum suntik menggunakan metode cutting hingga menjadi potongan jarum suntik berukuran milimeter[5]. Peneliti lainnya melakukan pengembangan menggunakan motor listrik yang menimbulkan polusi suara dan debu serbuk logam. Dapat diambil hipotesa bahwa mesin penghancur limbah jarum suntik yang telah ada menimbulkan dampak negatif terhadap pengguna dan orang lain disekitarnya. 
Penelitian ini berupaya menyajikan metode yang lebih aman untuk menghancurkan limbah jarum suntik.

\section{METODE PENELITIAN}

Untuk mencegah dampak lain yang cukup berbahaya dari proses penghancuran jarum suntik maka akan disajikan metode melting, yaitu metode peleburan logam dengan memanfaatkan arus listrik[6]. Langkah yang ditempuh untuk membuat rekayasa mesin penghancur disajikan dalam diagram pada Gambar 1 berikut ini.

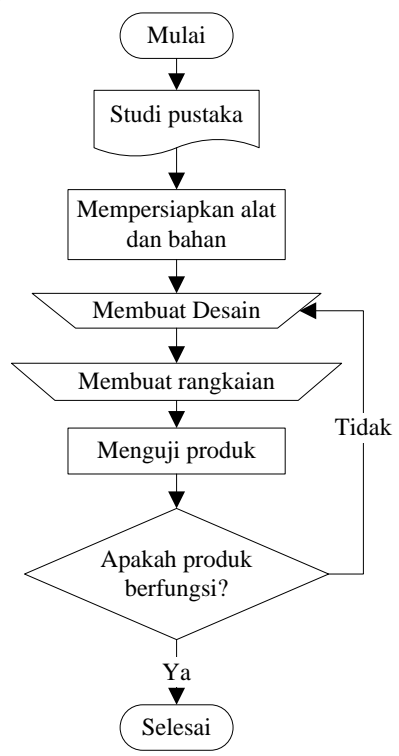

Gambar 1. Tahapan Penelitian

\section{HASIL DAN PEMBAHASAN}

\subsection{Perancangan}

Pengembangan purwarupa mesin penghancur limbah jarum suntik dimulai dengan membuat desain alur proses kerja menggunakan Bizagi Process Modeler versi 2.0. Hasil rancangan proses berupa diagram seperti yang ditunjukkan pada Gambar 2. Diagram tersebut menggambarkan satu siklus kerja.

Proses dimulai setelah saklar power supply dihidupkan, maka jarum suntik dimasukan ke lubang penghancur lalu sensor optocoupler akan mendeteksi objek. Jika sensor berhasil mendeteksi adanya obyek maka switch arus $12 \mathrm{~V}$ akan masuk ke motor listrik. Rancangan modul optocoupler ditunjukkan pada Gambar 3. Ketika sensor berhasil mendeteksi obyek maka arus listrik masuk ke motor listrik yang menempatkan obyek ke transformator sehingga arus tegangan tinggi pada transformator melewati obyek yang mengakibatkan obyek tersebut panas kemudian meleleh.

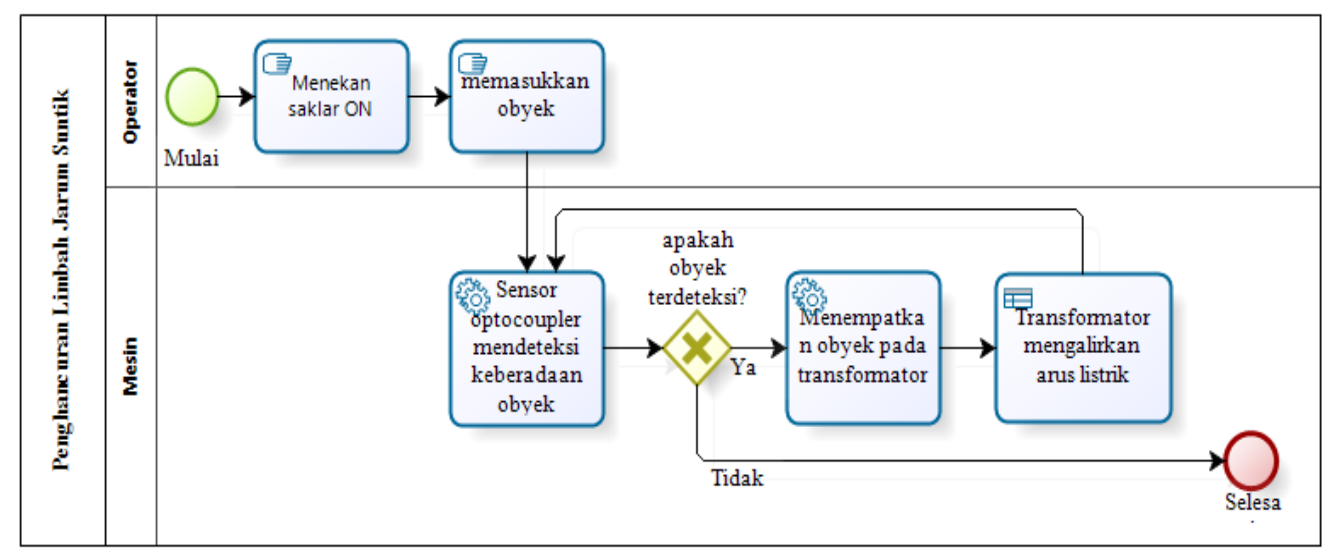

Gambar 2. Diagram Alur Proses Kerja Mesin Penghancur Jarum Suntik

Medika Teknika : Jurnal Teknik Elektromedik Indonesia, Vol 02 No. 2, April 2021 | 63 


\subsection{Implementasi}

Transformator akan berhenti bekerja jika sensor tidak mendeteksi ada obyek yang masuk ke lubang penghancur. Rancangan diagram ditunjukkan pada Gambar 3.

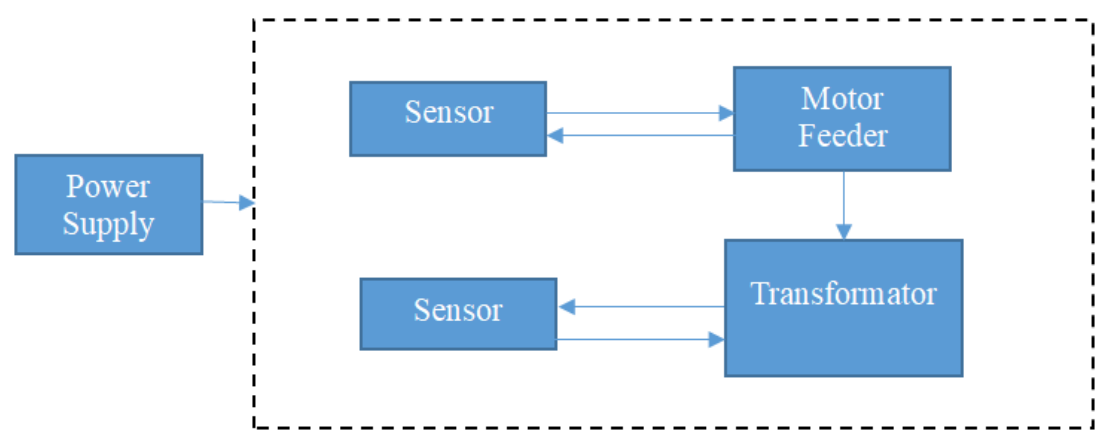

Gambar 3. Diagram Blok Mesin Penghancur Jarum Suntik

Rancangan fisik mesin penghancur limbah jarum suntik dapat dilihat pada diagram mekanik yang disajikan oleh Gambar 4 berikut ini.

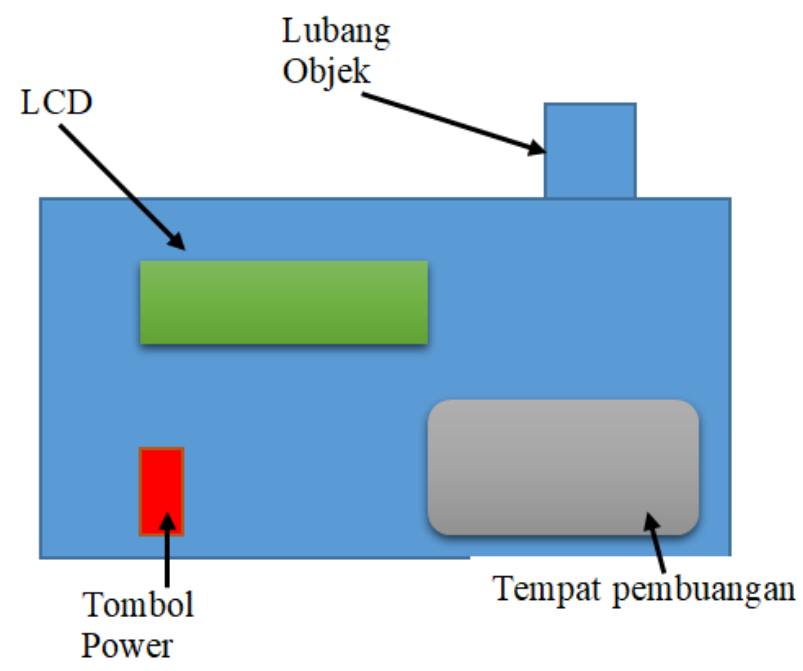

Gambar 4. Diagram Mekanik Mesin Penghancur Jarum Suntik

Lubang objek merupakan tempat untuk memasukkan jarum dengan posisi vertikal. Jarum yang dimasukkan akan dideteksi oleh sensor infra merah. Data dari sensor infra merah akan diproses oleh mikrokontroler untuk menghidupkan motor feeder. Selanjutkan sensor optocoupler akan mendeteksi gerakan jarum. Data dari sensor optocoupler diolah oleh mikrokontroler untuk mengaktifkan transformator. Proses aliran listrik melalui transformator akan terhenti jika sensor optocoupler tidak mendeteksi adanya jarum suntik yang digerakkan oleh motor feeder.

\subsection{Hasil Pengujian}

Pengujian fungsi dilakukan dengan melakukan percobaan pada beberapa jenis ukuran jarum suntik dan diperoleh hasil seperti pada Tabel 1 dibawah ini. Diameter terdiri dari diameter luar dan diameter dalam. Nomor jarum menunjukkan angka gauge. Semakin besar nomor gauge maka semakin kecil diameter jarumnya.

Tabel 1. Data Pengujian Penghancuran Jarum Suntik

\begin{tabular}{|l|l|l|l|l|l|}
\hline No. & Percobaan ke & $\begin{array}{c}\text { Nilai } \\
\text { Gauge }\end{array}$ & $\begin{array}{c}\text { Diameter Luar } \\
(\mathrm{mm})\end{array}$ & $\begin{array}{c}\text { Diameter Dalam } \\
(\mathrm{mm})\end{array}$ & $\begin{array}{c}\text { Waktu Lebur } \\
\text { (detik) }\end{array}$ \\
\hline 1. & 1 & 10 & 3.404 & 2.692 & 15 \\
\hline 2. & 2 & 11 & 3.048 & 2.388 & 7 \\
\hline 3. & 3 & 12 & 2.769 & 2.159 & 6 \\
\hline 4. & 4 & 13 & 2.413 & 1.803 & 6 \\
\hline
\end{tabular}

Medika Teknika : Jurnal Teknik Elektromedik Indonesia, Vol 02 No. 2, April 2021 | 64 


\section{Widadi, Fajrin, Kartika}

Rekayasa Penghancur Limbah Jarum Suntik Menggunakan Metode Melting

\section{KESIMPULAN}

Penelitian ini menghasilkan kesimpulan bahwa metode melting mampu menghancurkan limbah jarum suntik dengan dampak polusi suara kurang dari $3 \mathrm{~dB}$, mampu membasmi bakteri dan virus pada objek karena titik lebur logam diatas $1000^{\circ} \mathrm{C}$ tetapi proses penghancuran membutuhkan waktu lebih lama dibandingkan metode cutting.

\section{DAFTAR PUSTAKA}

[1] H. S. K. Oktaviana Zahratul Putri, Tengku Mohamed Ariff Bin Raja Hussin, "Analisis Risiko Keselamatan dan Kesehatan Kerja pada Petugas Kesehatan Instalasi Gawat Darurat Rumah Sakit Akademik UGM," J. Kesehat., vol. 10, no. 1, pp. 1-12, 2017.

[2] O. Putri, M. Tengku, A. B. R. Hussin, and H. Kasjono, "Analisis Risiko Keselamatan Dan Kesehatan Kerja Pada Petugas Kesehatan Instalasi Gawat Darurat Rumah Sakit Akademik UGM," J. Kesehat., vol. 10, no. 1, pp. 1-12, 2017.

[3] B. L. Sanyoto et al., "Mesin penghancur sampah jarum suntik dan tabung suntik plastik," pp. 242-248, 2018.

[4] T. W. Indri Meilawati, Yuli Prapancha, "Faktor-Faktor Yang Berhubungan Dengan Kejadian Luka Tusuk Jarum Suntik Pada Perawat Di Rumah Sakit Bhayangkara Brimob Tahun 2018," J. Bid. Ilmu Kesehat., vol. 9, no. 1, pp. 24-36, 2018.

[5] S. H. A. Lagimpe and M. J. Miswan, "Sistem Pengolahan Sampah Medis Dan Non Medis Di Rumah Sakit Umum Daerah Poso," J. Kolaboratif Sains, vol. 1, no. 1, 2018.

[6] J. Campbell, "Melting, Remelting, and Casting for Clean Steel," Nat. Scences, vol. 88, no. $1,2016$. 